\title{
REBRANDING PRODUK KERIPIK JAMUR TIRAM UNTUK PENINGKATAN PENJUALAN PADA UMKM SPORAMUSHROOM
}

\author{
Andi Iva Mundiyah, Dudi Septiadi, Sharfina Nabila, Ni Made Wirastika Sari, Ni Made \\ Zeamita $^{1}$
}

${ }^{1}$ Fakultas Pertanian Universitas Mataram

e-mail: andiva@unram.ac.id

\begin{abstract}
Abstrak
UMKM Sporamushroom yang mengolah jamur tiram menjadi olahan keripik jamur tiram yang berlokasi di Jalan Pelita Kota Makassar. Jamur tiram adalah olahan pangan yang memiliki banyak manfaat bagi tubuh, rasa yang gurih serta teksturnya menyerupai daging ayam sehingga hampir semua kalangan menyukainya. Permaslahan yang dihadapi oleh UMKM Sporamushroom pada kemasan keripik jamur yang tidak menarik serta tidak mampu menjaga daya tahan dari produk yang ada di dalamnya. Permasalahan lain yang dihadapi adalah brand atau merk dari keripik jamur yang belum tetap. Hasil kegiatan yang dilakukan menunjukkan perlunya pendampingan dan sharing informasi tentang jenis-jenis kemasan untuk olahan keripik sehingga akan dihasilkan kemasan yang sesuai dengan produk yang dipasarkan, penggunaan kemasan plastik aluminium sesuai untuk produk olahan keripik. Dari aspek merk, pemilihan merk yang tepat dan mudah diingat oleh komsumen berpengaruh pada penjualan produk. Merk JAMBUL dipilih sebagai merk keripik jamur tiram karena mudah diingat dan memiliki filosofi dibalik nama tersebut.
\end{abstract}

Kata Kunci: Merk, Pemasaran, Kemasan, UMKM

\section{A. Pendahuluan}

Kegiatan pemasaran tidak terlepas dari konsep dasar pemasaran yaitu proses pemasaran produk melalui seperangkat alat pemasaran yang terdiri dari produk, price, place, dan promotion (Kotler, 2002). Keripik jamur tiram merupakan salah satu produk cemilan berbahan dasar jamur tiram putih yang mulai banyak di tawarkan karena rasanya yang lezat dan gurih serta teksturnya menyerupai daging ayam sehingga banyak disukai oleh kalangan masyarakat. Menurut Muchtadi (2010), jamur tiram mempunyai rasa yang enak seperti daging ayam, bahkan jamur tiram ini disukai sebagian besar orang di dunia karena rasa khasnya dan manfaatnya bagi kesehatan.

Diversifikasi pengolahan jamur tiram sangat dibutuhkan oleh petani dan pengusaha olahan jamur tiram dalam meningkatkan nilai tambah jamur segar (Usdyana dkk., 2018). Jamur tiram putih masuk dalam kategori bahan pangan karena aman dan tidak beracun 
sehingga dapat dikomsumsi. Selain aman, jamur tiram putih merupakan salah satu bahan makanan bernutrisi tinggi. Dari beberapa penelitian diungkapkan bahwa jamur tiram putih mengandung senyawa antidiabetes, antibakterial, antikolesterol, antiartritik, antioksidan, antikanker, baik untuk kesehatan mata serta mengandung senyawa aktif polisakarida yang disebut beta-glucan.

UMKM Sporamushroom merupakan salah satu pelaku usaha yang bergerak dibidang pengolahan bahan makanan dengan bahan baku utama jamur tiram putih. Produk yang dihasilkan adalah keripik jamur tiram dengan beberapa varian rasa. Usaha ini beralamat di Jalan Pelita Raya Kota Makassar. UMKM ini mempekerjakan 4 orang serta memiliki mitra petani jamur yang bertugas memasok jamur tiram putih segar setiap dua hari sekali. UMKM ini dapat mengolah 5-10 kg jamur tiram segar untuk dijadikan keripik jamur.

Dari hasil pengamatan dan wawancara dengan Bapak Hendra selaku pemilik usaha keripik jamur diperoleh informasi adanya pelatihan yang diberikan kepada UMKM Sporamushroom tentang pengolahan jamur tiram menjadi keripik jamur. Dari hasil pengamatan lapangan, keripik jamur yang dihasilkan rasanya gurih dan renyah namun tidak tahan lama karena tingginya kandungan minyak dalam keripik jamur. Kemasan keripik yang digunakan berbahan plastik tipis yang tidak kedap udara sehingga mempengaruhi kualitas keripik dalam jangka panjang. Hasil kajian Ramli (2017) menyimpulkan pembuatan kemasan, brosur, dan pemanfaatan media sosial lebih memudahkan mitra dalam melakukan kegiatan promosi untuk dapat meraih komsumen baik lokal maupun skala nasional.

Kegiatan ini bertujuan untuk mengedukasi UMKM Sporamushroom tentang jenisjenis kemasan terkhusus untuk olahan keripik dan memberikan masukan tentang merk yang bagus dan mudah diingat oleh calon komsumen untuk keripik jamur yang dijual.

\section{B. Masalah}

Berdasarkan hasil diskusi dengan pemilik UMKM. Permasalahan yang dihadapi bagaimana pengembangan produk keripik jamur tiram kedepannya agar dikenal oleh masyarakat dan dapat menjadi buah tangan bagi wisatawan lokal maupun wisatawan asing ketika mengunjungi kota Makassar. Secara garis besar permasalahan mitra dapat di kelompokkan sebagai berikut:

a. Dari aspek produk keripik jamur 
Hasil akhir dari keripik jamur masih mengandung banyak minyak sehingga mudah kemasukan udara dan tidak tahan lama

b. Dari aspek kemasan.

Kemasan yang digunakan masih menggunakan plastik tipis yang kemudian dimasukkan dalam kotak karton tipis sebagai kemasan luar dari keripik jamur.

c. Dari aspek merk.

Belum ada merk tetap yang di pasang pada kemasan luar dari keripik jamur tiram.

d. Dari Aspek pemasaran

Keripik jamur tiram dipasarkan di sekitar wilayah Kota Makassar saja dikarenakan keripik hanya mampu bertahan 3 (tiga) hari setelah di kemas.

\section{Metode Pelaksanaan.}

Dari permasalahan yang ditemukan dilapangan dan juga berdasarkan atas permintaan mitra di dalam kegiatan pendampingannya, maka tim melaksanakan kegiatan pendampingan yang terfokus pada 2 kegiatan utama yaitu:

a. Pendampingan dalam pemilihan kemasan produk

Pendampingan ini bertujuan untuk mengedukasi pemilik UMKM untuk tidak asal memilih dan menggunakan kemasan untuk produk keripik jamur tiram. Kemasan berfungsi sebagai atribut dari produk yang akan dipasarkan, selain itu kemasan juga mempengaruhi daya tahan suatu produk.

b. Pendampingan dalam pemilihan dan penggunaan merk produk

Merk memiliki fungsi sebagai pembeda antara produk yang sejenis. Banyaknya olahan keripik jamur tiram di pasaran sehingga merk sangat penting dari sebuah produk. Merk yang mudah diingat oleh komsumen menjadi nilai tambah bagi produk ketika di pasarkan.

Kegiatan pendampingan UMKM lebih kepada peningkatan pemasaran produk UMKM yaitu keripik jamur tiram, sehingga produk UMKM dapat dikenal luas dan mampu bersaing dengan produk cemilan yang lain serta mampu memasuki retail-retail yang ada di Kota Makassar yang pada akhirnya mampu meningkatkan taraf ekonomi pemilik dan para pekerja di UMKM Sporamushroom. Dari dua kegiatan pendampingan yang menjadi fokus kegiatan ini dapat dijabarkan pada pembahasan. 


\section{Pembahasan}

1. Pemilihan Kemasan Produk

Kemasan produk dan merk selain berfungsi sebagai pengaman produk yang terdapat di dalamnya juga berfungsi sebagai media promosi dan informasi dari produk yang bersangkutan. Kemasan produk yang baik dan menarik akan memberikan nilai tersendiri sebagai daya tarik komsumen. Namun demikian hingga saat ini kemasan produk menjadi masalah yang cukup mengganggu baik pelaku usaha terutama UMKM. Abdullah, T dan Francis, T (2012) mengatakan pengemasan termasuk aktifitas merancang dan membuat wadah atau pembungkus suatu produk. Kemasan produk adalah bagian pembungkus dari suatu produk yang ada di dalamnya, merupakan salah satu cara untuk mengawetkan dan memperpanjang umur produk-produk pangan atau produk yang ada di dalamnya.

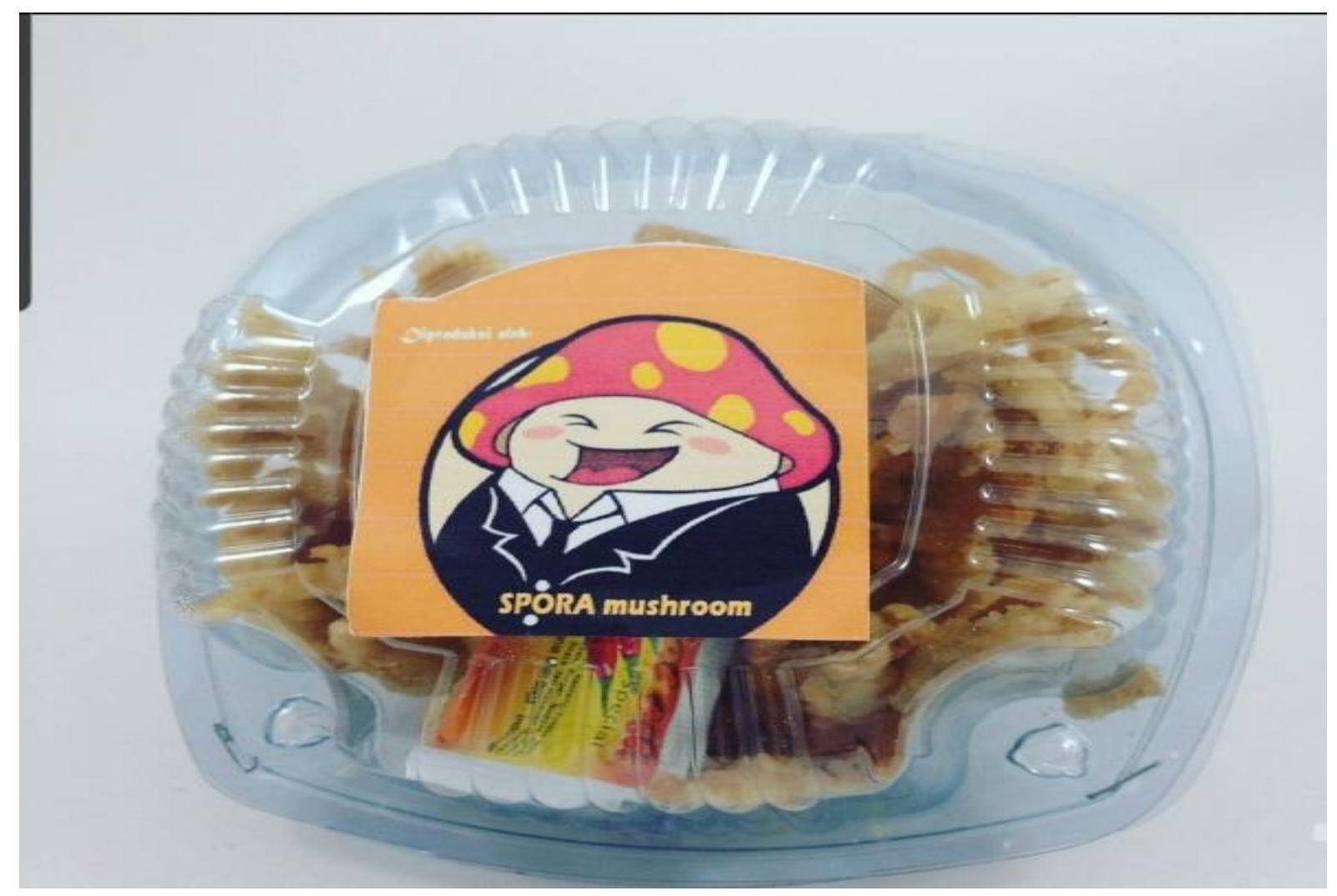

Gambar 1. Kemasan Keripik Pertama 

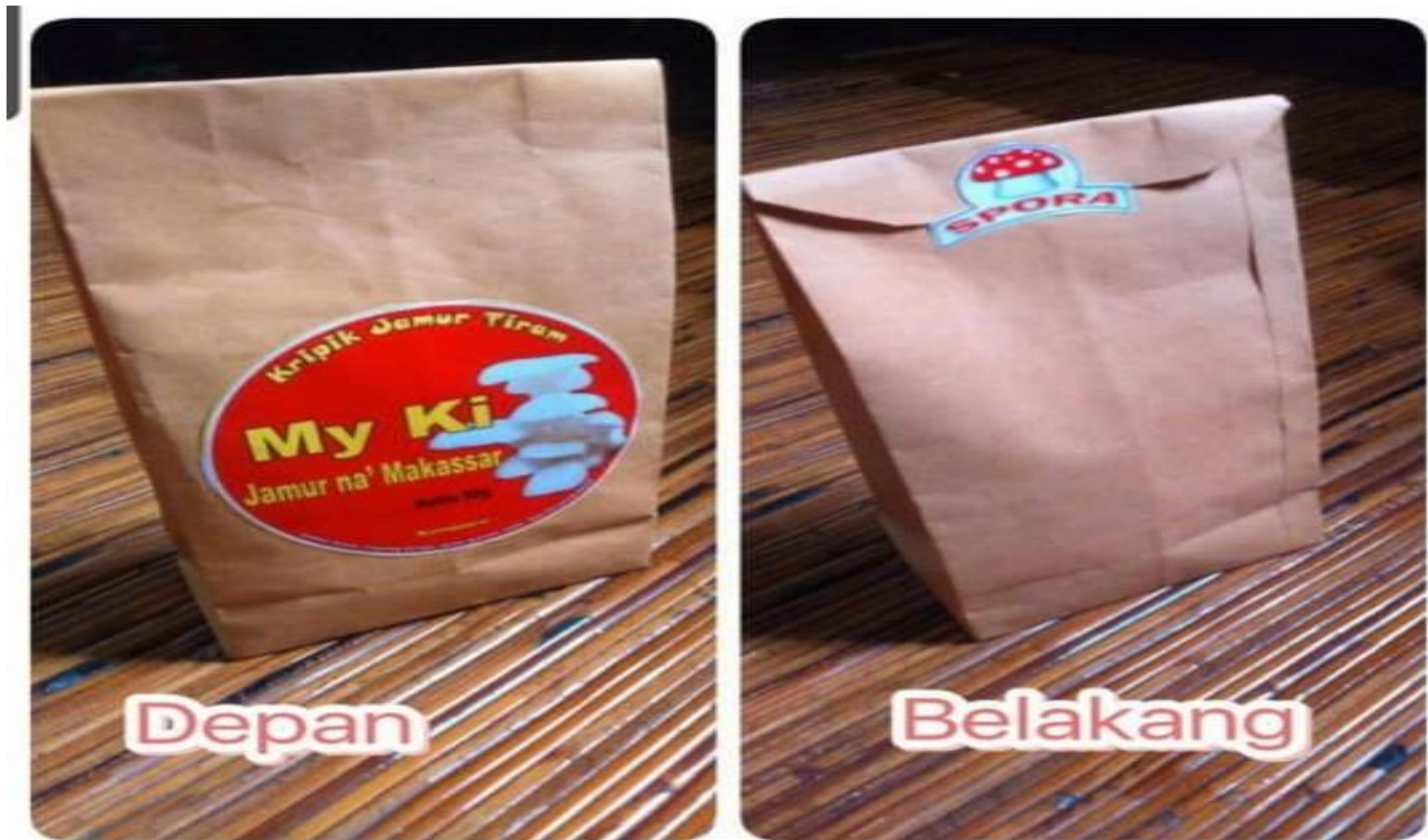

Gambar 2. Kemasan Keripik Kedua

Kedua kemasan keripik jamur tiram yang digunakan oleh UMKM Sporamushroom kurang dapat mempertahankan kualitas dan umur produk keripik jamur yang dihasilkan sehingga berpengaruh pada jumlah keripik yang terjual dikarenakan keripik mudah kemasukan udara karena masih adanya udara yang dapat masuk pada kemasan. Dari hasil evaluasi kemasan yang pernah digunakan oleh UMKM Sporamushroom, maka kemasan berbahan plastik aluminium dan transparan cocok untuk produk keripik jamur tiram untuk menjaga kualitas dan memperpanjang umur produk. Menurut hasil penelitian Veranita, M (2013) faktor yang mengaruhi kemasan kerupuk warna dasar kemasan, ukuran kemasan, bentuk kemasan dan merk kemasan. Warna bening (transparan) menjadi warna yang paling disukai oleh komsumen. Bahan plastik, kaleng, aluminium foil dan lainnya dapat digunakan untuk mencegah masuknya gas, melindungi kandungan air dan kerusakan lain pada produk tersebut. 


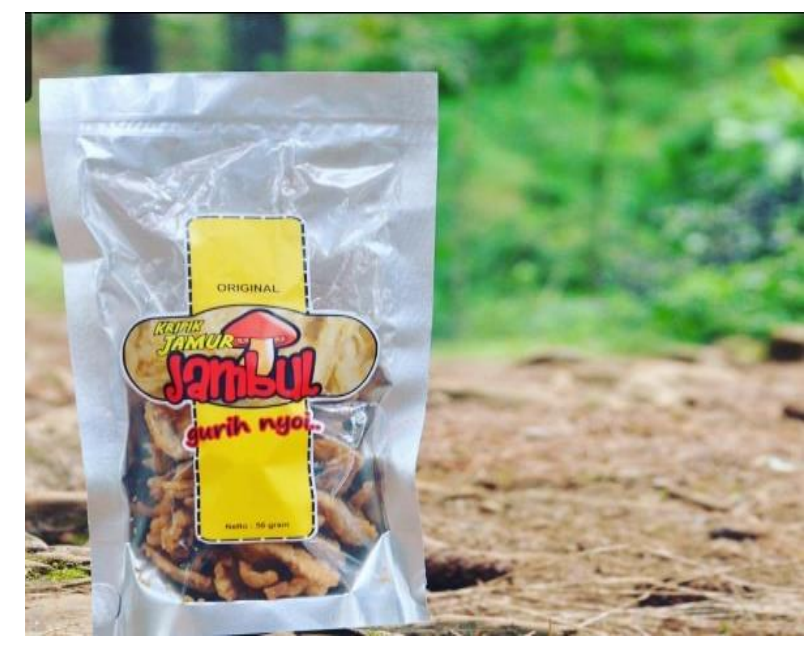

Gambar 3. Kemasan Keripik Yang Sekarang

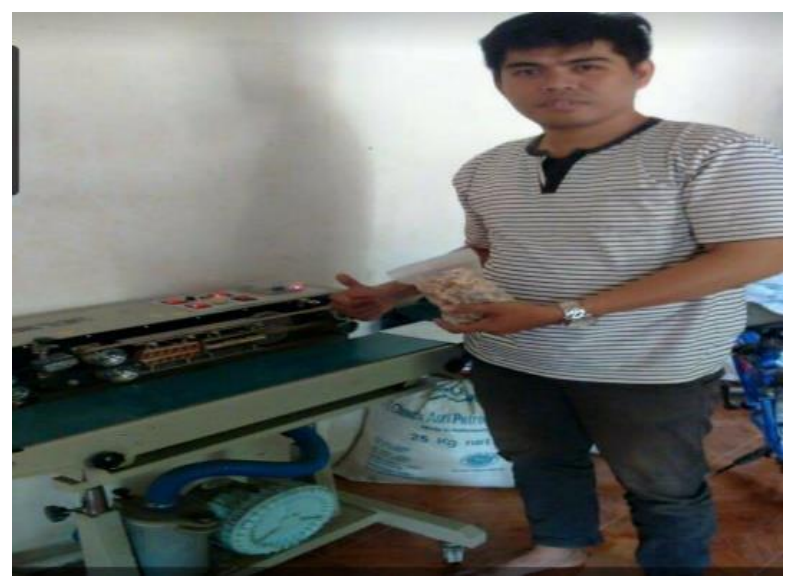

Gambar 4. Mesin Vacum Frying Pada Pengemasan

Merk atau label adalah keterangan atau pernyataan produk yang berbentuk gambar, tulisan, kombinasi keduanya atau bentuk lain yang disertakan, dimasukkan ke dalam, ditempelkan atau merupakan bagian kemasan. Dari hasil diskusi dengan pemilik UMKM Sporamushroom diperoleh kesepakatan menggunakan merk JAMBUL untuk keripik jamur tiram, alasan dibalik penamaan nama tersebut karena 1. merk JAMBUL mudah diingat dibandingkan dua merk yang digunakan sebelumnya, 2. Filosofi jambul yang berada diatas kepala sehingga pemilik UMKM berharap usahanya selalu berada di atas dan berkembang pesat. Merk JAMBUL dicetak diatas plastik agar tidak mudah rusak jika terkena air, menggunakan warna merah agar mudah terlihat dan dari hasil penelitian yang ada warna merah cenderung membuat rasa lapar bagi yang melihatnya. Keripik jamur tiram ini akan dipasarkan di toko-toko, toko ole-ole, retail dan membuka kemitraan dengan sistem reseller. 
Dengan kegiatan rebranding produk keripik jamur tiram mampu memperluas area pemasarannya sehingga memberi pengaruh terhadap peningkatan pendapatan pelaku UMKM

\section{E. Kesimpulan}

Kesimpulan dari program pengabdian kepada masyarakat adalah: (1) Dari aspek kemasan, kegiatan pendampingan yang dilakukan adalah berbagai informasi tentang jenisjenis kemasan untuk olahan keripik dan memberi penjelasan kelebihan dan kekurangan dari jenis-jenis kemasan. Hasil akhir UMKM Sporamushroom mengganti kemasannya menggunakan plastik aluminium dan menggunakan mesin vacum untuk menjaga agar udara tidak masuk dalam kemasan; (2) Merk JAMBUL dipilih oleh pemilik usaha dengan alasan mudah diingat serta memiliki filosofi dibalik nama tersebut.

\section{DAFTAR PUSTAKA}

Abdullah, T. dan Francis T. (2012). Manajemen Pemasaran. Jakarta: Raja Grafindo Persada.

Muchtadi D. (2010). Teknik Evaluasi Nilai Gizi Protein. Bandung: Penerbit Alfabeta.

Kotler, P. (2002). Manajemen Pemasaran. Prentice Hall. Inc, New Jersey.

Ramli, Rusman M. 2017. Pemasaran Produk Hasil Rumput Laut di Desa Waara Sebagai Pintu Gerbang Pulau Muna. Jurnal Pengabdian Kepada Masyarakat Membangun Negeri Vol 1 (1) hal 78.

Usdyana dkk., 2018. Diversifikasi Jamur Tiram Sebagai Pangan Lokal Pada Kelompok Wanita Tani Di Kecamatan Malua Kabupaten Enrekang. Jurnal Dedikasi Masyarakat Vol 1 (2) Hal 60.

Veranita, M. 2013. Strategi Pemasaran Produk Makanan Olahan Melalui Pengemasan dan Pemerkan. Jurnal EKBIS (Ekonomi dan Bisnis) Vol. 1 (1) Hal. 1-13. 